European Journal of English Language and Literature Studies

Vol.10, No.1, pp.1-15, 2021

Print ISSN: 2055-0138(Print),

Online ISSN: 2055-0146(Online)

\title{
TEACHERS' BELIEFS, THE CONCEPT OF FACE AND CLASSROOM PRACTICES
}

\section{Dr. Ogerta Koruti Stroka ${ }^{1}$ and Dr. Etleva Kondi Koni ${ }^{2}$}

${ }^{1,2}$ University of Tirana, Faculty of Foreign Languages, Albania

\begin{abstract}
Students who want to be English language teachers enter teacher preparation programs viewing, teaching and learning from their own experience as students as pointed out by many researchers (e.g., Curtner-Smith, Hastie, \& Kinchin, 2008; Richardson, 1996; Russell, 2008, Schweisfurth 2015). They want to teach the way they were taught while they were at the universities. Often, they have a role model, a teacher who serves as a guide an inspiration for them. After they graduate and start working as English teachers, what they face, in reality, sometimes overlaps with the information they were given as students. So, their beliefs about teaching alter and change depending on their teaching contexts. Relating theory and practice enables pre-service teachers to transfer the necessary knowledge and skills gained at the university level on actual teaching practice (Bell \& Robinson, 2004). Awareness and enhancing educational processes require an understanding of teachers' views and actions. They are closely linked to teachers'strategies for coping with challenges and difficulties in their daily teaching routines and at the same time they influence students' motivation about the learning process. The purpose of this paper is to address the importance of teachers' beliefs and actual classroom practices about the importance of teaching prepositions in their classes. Also, the concept of face, loosing or saving face be it of the teachers or students is introduced in this paper. Cases when teachers' beliefs converge or diverge with real class practices are discussed pointing out the factors that influence teaching practices. Teachers' beliefs and current practices are important for understanding and improving the educational processes. The authors will compare the teachers' beliefs and their actual practices in English classes and how is the concept of face employed in EFL classes. For the purpose of this paper, three English teachers out of 20 were randomly selected during a training seminar provided By British Council, Albania. The concept of face is examined through three English teachers who teach at a primary school and are observed how they provide explanation, regarding prepositions, to their students. The findings show that the concept of face is not introduced to students in any class or subject. It is recommended that students should be taught about the concept of face, types of face, how they are related to individuals and the influence that the concept of face has on teachers' daily teaching routines. Moreover, there is no study on the concept of face in the Albanian context and especially in the EFL classes. So, in the future other studies are needed to stress the importance of the concept of face in the Albanian culture.
\end{abstract}

KEY WORDS: teachers' beliefs, practices, face, teaching process, EFL classrooms

@ECRTD-UK https://www.eajournals.org/

https://doi.org/10.37745/ejells.2013 


\section{INTRODUCTION}

\section{TEACHER BELIEFS}

Parajes (1992) describe teacher beliefs as "a cluster of thoughts, perceptions, values, judgments, attitudes, and behaviors that have an important effect on the teaching practices of teachers." Tobin, Tippins, and Gallard (1994) define teachers' beliefs as "a form of knowledge that is personally viable in the sense that it enables a person to meet his or her goals."

Johnson (1994) suggests that teacher beliefs are neither easy to define nor study because they are not directly observable. He draws the attention on three assumptions regarding teachers' beliefs:

1. Their influence on perception and judgment;

2. Their attitude on how information on teaching is translated into classroom practices;

3. Improvement of teaching practices and teacher education programs.

Ng \& Farrell, (2003) and Yim (1993) investigated the extent to which teachers' theoretical views impact their classroom practices, and found that what instructors say and do in the classroom is governed by their beliefs. Farrell (1999) investigated the views of pre-service English grammar instructors in terms of their impact on teaching practice, and discovered evidence that these beliefs are resistant to change. Teachers of English as a foreign language are aware of the notorious difficulties that Albanian students encounter in the process of mastering English prepositions. Studies have shown the complexity and the difficulties of this part of speech for Albanian learners of English at different linguistic levels (Dheri 1981, Samara 1999).

This paper examines the way three English teachers at a primary school provide explanation, regarding prepositions, to their students. Particularly, it aims at shedding some light on the following research question:

1. What are the two teachers' beliefs about the way English prepositions should be taught in primary schools?

2. What are their practices of teaching prepositions in their classes?

3. The concept of face while working with prepositions

@ECRTD-UK https://www.eajournals.org/

https://doi.org/10.37745/ejells.2013 


\section{METHODOLOGY}

\section{Participants}

For the purpose of this study, three English teachers out of 20 were randomly selected during a training seminar provided By British Council, Albania. Teachers were introduced with the study and were asked for their availability. A selection criterion used was the range of years of their teaching experience. The selected teachers teach full-time at two primary schools in Tirana, Albania.

\section{Data Collection}

Three teachers and three classes (with approximately 36 students per class) participated in this study. All the teachers were non-native speakers of English. Two teachers were females (Teacher $1 \&$ teacher 2), and one was a male (Teacher 3), and their teaching experience varied from five years to 32 years. The three of them held Master Degrees in Teaching. All the students were Albanian, and English was a foreign language for them. There were 57 females, and 51 are males.

For the purpose of this study, we adopted a qualitative approach to investigate the relationship between teachers' beliefs and their actual classroom practices with regards to prepositions and how the concept of face is integrated in EFL classes. Gass and Mackey (2013) believe that through observations, researchers can gather data on the events, interactions and patterns of language use within particular EFL/ESL classrooms. Three classroom observations with two observations in each class were both video and audio recorded for the importance of embodied aspects of explanation of prepositions (classes last $45 \mathrm{~min}$ ).

Furthermore, data included one scheduled interview with each of the teachers. Before the classes, the selected teachers provided me with detailed lesson plans to create an idea about the way they organized their classes and how they dealt with prepositions in their teaching routines. The interview questions were designed to elicit information about the teachers' beliefs regarding prepositions and the way they are taught, the techniques and methods used by them. Other questions attempted to discover more about the teachers' actual teaching techniques as well as the factors that influenced their approach and strategy choices. Each of the interviews lasted 30-35 min. Even so, due to time constraints, and other circumstances beyond our control, we couldn't observe more than six classes.

@ECRTD-UK https://www.eajournals.org/ https://doi.org/10.37745/ejells.2013 


\section{DATA ANALYSIS}

\section{BELIEFS}

Table 1 summarizes the general data obtained from the interviews, and helps to give a clear a picture concerning the teachers' beliefs regarding prepositions, and the way they are taught.

\section{Table 1. Teachers' beliefs}

\begin{tabular}{|c|c|c|c|}
\hline Teachers' Belief & Teacher 1 & $\begin{array}{l}\text { Teacher } \\
2\end{array}$ & Teachers 3 \\
\hline Prepositions are very confusing & $\mathrm{X}$ & $X$ & $\mathrm{X}$ \\
\hline $\begin{array}{l}\text { Prepositions are hardly addressed in current ESL } \\
\text { teaching methods. }\end{array}$ & $X$ & & $X$ \\
\hline $\begin{array}{l}\text { Many English textbooks simply give a broad } \\
\text { overview of prepositions and don't go into detail } \\
\text { about how to use them. }\end{array}$ & $X$ & & $X$ \\
\hline $\begin{array}{l}\text { Prepositions are taught by giving several } \\
\text { evidences of their use in multiple settings. }\end{array}$ & & $X$ & $X$ \\
\hline $\begin{array}{l}\text { Students need to know the grammar rules when } \\
\text { and how prepositions are used. }\end{array}$ & $\mathrm{X}$ & $\mathrm{X}$ & \\
\hline $\begin{array}{l}\text { Beginners in English are likely to use a preposi- } \\
\text { tion translated from their mother tongue to the } \\
\text { target language. }\end{array}$ & & $\mathrm{X}$ & \\
\hline $\begin{array}{l}\text { Prepositions are problematic for non-native } \\
\text { English speakers in three ways: they choose the } \\
\text { inappropriate prepositions, they miss a necessary } \\
\text { preposition, and they use an extra preposition } \\
\text { where one is not required. }\end{array}$ & $X$ & $X$ & $X$ \\
\hline
\end{tabular}

As outlined in the Table 1 . the three teachers agree that prepositions are very confusing and sometimes hardly understandable even for native speakers. They also stated that the challenge is considerably worse for EFL students, as they must comprehend all of the complexities of English prepositions, memorize them, and utilize them correctly. 
Teacher 1 and Teacher 3, believe that prepositions are hardly addressed in current ESL teaching methods as a consequence they often find prepositions hard to teach. When they want to explain a preposition, they will sometimes utilize one or two additional prepositions to create a definition, which will then lead to other explanations. This scenario is perplexing not only for professors, but also for students, who find themselves in a "pool" of prepositions whose meanings are still ambiguous. Furthermore, Teacher 1 and Teacher 3, think that Many English course books provide only a general overview of prepositions and do not supply specific rules on their usage. Important features of preposition acquisition, such as when a certain preposition has more than one meaning depending on its context, as well as a lack of information about verbs or nouns that may necessitate specific prepositions, are rarely emphasized. Teacher 1 and Teacher 3 referred to the course books that they have used in the past or are currently using with their students to point out that in some of them, prepositions are not mentioned at all, leading to difficulties for English teachers when they explain them (World Link (Stempliski, Douglas \& Morgan, 2004) Click On 1, Click On 2, Click On 3 (Evans \& O’Sullivan 2001). Additionally, they mentioned other textbooks such as Inside Out (Kay Jones \& Kerr) and Straightforward Intermediate and Upper Intermediate (Kerr \& Jones, 2007) where prepositions are taught at certain proficiency levels and generally only deal with just two of their most common usages: spatial and temporal use.

The three teachers strongly believe that prepositions can be taught by providing multiple examples within a given context. Teacher 1 mentioned some activities that she uses with her students such as: as "Listen and draw"; "Listen and do"; "Listen and write" depending on their age level and linguistic competence. She shows her students what to listen for - in this case, prepositions, when they have listening spots, when they are performing dialogues, or when they are giving/ receiving directions. Once the students learn to listen and recognize these linking words the only problem is to train them to properly select prepositions, depending on the context used, their idiomatic and metaphorical uses. While students perform the "Listen and do" task, they are expected to raise their hands, clap their hands, move around or repeat the preposition in chorus, etc. whenever they hear a preposition.

The "Listen and draw" task may be used not only with students but even with adults when teachers want to teach prepositions with less abstract reference. So, teachers may say short, simple sentences such as:

The book is on the table.

And the students are expected to draw a pen on a table.

@ECRTD-UK https://www.eajournals.org/

https://doi.org/10.37745/ejells.2013 
Teacher 2 suggests some other activities as for example: reading books, or playing CD-s with short text or songs, which make use of different types of prepositions; filling in the missing preposition or circling the right preposition. They may also ask their students to write a description of their favorite place, to describe a birthday party, or to write a letter to a pen friend using at least 10 prepositions.

Teacher 3 is of the idea of engaging as many senses as teachers can so their students can easily grasp the correct usage of prepositions. He brings different pictures to illustrate the usage of specific prepositions, such as:

Flashcards or posters- illustrating specific prepositions such as on, in, and at, for example:

The pencil is on the table; I'll meet him at 10 o'clock at the bus station.

He also presents a schematic picture, a map, where prepositions of place and movement are used. Sometimes, he says, he brings real objects in the class so that students can use them to express the correct usage of different prepositions in different contexts.

When learning a second language, there are causes of contention because each language has its own set of grammar rules (James, 2007; Jie, 2008). The most crucial component of these conflict spots is typically prepositions. In English, prepositions are usually placed before the noun, but in certain languages, they are placed after the noun, making them postpositions (Samara, 1999). In some languages, including Albanian, the role of prepositions is often played through the use of inflections (Demiraj, 1986). As a result, prepositions in different languages function differently grammatically. So, Teacher 1 and Teacher 2 argued that students need to know the grammar rules when and how prepositions are used. Prepositions in English can appear as adjuncts, indicate predicates' arguments, and combine with other parts of speech to generate new meanings. There is a mismatch problem between English and other languages (Celce-Murcia \& Larsen-Freeman, 1999). When learning a foreign language, it is common for someone to try to define an English word by its native counterpart.

Teacher 2 stated that students try to translate the English preposition with the equivalent in his/ her mother tongue. So, beginners in English are likely to use a preposition translated from their mother tongue to the target language (English), and this is rarely the right one. She argues that it's easy to understand and use English content words like table or chair connected with an object of daily use but if Albanian students try to find the correct equivalent of function words, like prepositions, they face difficulties. She has

@ECRTD-UK https://www.eajournals.org/ 
noticed that her students struggle to find the exact prepositions due to many different meanings that prepositions have, depending on the context used. She also thinks that when her students use prepositions when not needed, they are due to mother tongue interference.The three teachers noted three common mistakes made by non-native English speakers: using the incorrect prepositions, deleting a necessary preposition, and employing an extra preposition where one is not required.

\section{Classroom Practices}

Table 2 outlines the three teachers' actual classroom practices when teaching English prepositions.

\section{Table 2: Teachers' Classroom Practices}

\begin{tabular}{|l|l|l|l|}
\hline Observed classes & Teacher 1 & Teacher 2 & $\begin{array}{l}\text { Teacher } \\
\mathbf{3}\end{array}$ \\
\hline $\begin{array}{l}\text { Classes were conducted in a traditional approach, with explicit } \\
\text { teaching grammar rules. }\end{array}$ & $\mathbf{X}$ & \\
\hline $\begin{array}{l}\text { Students are given no grammar rules; prepositions are taught } \\
\text { through examples and drills. }\end{array}$ & & $\mathbf{X}$ & $\mathbf{X}$ \\
\hline Teacher-centered classes, teacher is the authority in class. & $\mathbf{X}$ & & $\mathbf{X}$ \\
\hline Pictures or realia are used to give meaning of prepositions. & $\mathbf{X}$ \\
\hline $\begin{array}{l}\text { The teacher does a contrastive comparison of the target language } \\
\text { and the students' native language to identify the areas where he or } \\
\text { she expects his or her students to struggle. }\end{array}$ & $\mathbf{X}$ & $\mathbf{X}$ \\
\hline The teacher asks students to state grammar rules. & $\mathbf{X}$ & & $\mathbf{X}$ \\
\hline Students apply a rule to examples they are given. & $\mathbf{X}$ & $\mathbf{X}$ \\
\hline $\begin{array}{l}\text { Positive reinforcement helped student to develop correct habits on } \\
\text { correct use of prepositions. }\end{array}$ & $\mathbf{X}$ & $\mathbf{X}$ & $\mathbf{X}$ \\
\hline The teacher tends to save her positive face. & $\mathbf{X}$ & $\mathbf{X}$ & $\mathbf{X}$ \\
\hline $\begin{array}{l}\text { When the teacher asks students questions about the correct use of } \\
\text { prepositions, they fight to preserve their face. }\end{array}$ & $\mathbf{X}$ & $\mathbf{X}$ & $\mathbf{X}$ \\
\hline Students see and think of their teachers as "walking encyclopedias". & $\mathbf{X}$ & $\mathbf{X}$ & $\mathbf{X}$ \\
\hline $\begin{array}{l}\text { Students' need for face-restoration (complaining about the } \\
\text { difficulties they face while they study prepositions). }\end{array}$ & $\mathbf{X}$ & $\mathbf{X}$ & \\
\hline
\end{tabular}

As illustrated in Table 2, Teacher 1 conducted classes in a traditional way, with explicit

@ECRTD-UK https://www.eajournals.org/

https://doi.org/10.37745/ejells.2013 
grammar rules explained first and then practiced in sentences, by the students in different contexts. Occasionally, she asks students to state the grammatical rules of the target language. Her classes were teacher-centered. Grammar was studied inductively; students are provided with grammar rules and are asked to memorize them. Then the teacher asked them to apply the rules to other examples. At the end, they did the exercises in the book related to prepositions: fill in the missing preposition, circle the right preposition.

No grammar explanation, regarding prepositions, in Teacher's 2 and Teacher's 3 classes are observed. Both teachers engaged their students in activities related to prepositions, different games, songs, etc. At the end teacher 2 asked her students to write an essay about their daily routine. When later asked by the researcher about the purpose of the essay, teacher 2 explained that she expected her students to make use of nouns, adjectives, the present tense and a great number of prepositions.

Teacher 2 and Teacher 3 made use of pictures, posters and flashcards where specific prepositions like on, in, with, below, under, in front of, behind, at are illustrated, for instance: The boy is behind the tree.

While explaining prepositions, Teacher 3 made use of real objects such as apples, books, rulers, duster, etc. He asked his students questions such as: Where is the duster?; Where is the apple? He also gave directions to the class: put the pencil in the bag; put the apple under the table; put the duster on the table. Then students followed the directions.

As given in Table 2, the last five classroom practices are observed in all the classes that the researcher attended. What attracted my attention as a researcher was the concept of face, be it active or passive; negative or positive. Passive face-saving had to do with the 'do no harm' philosophy and in the classes that we observed, the teachers tended to avoid doing gestures or giving negative feedback not to embarrass their students. Active face saving had to with the empathy showed by the teachers to their students when they faced difficulties while using prepositions.

Being part of Eastern part of Europe (still recovering from a 50 year dictatorship regime and now for more than 21years of a fragile "democracy") and influenced by our culture the concept of "saving/loosing face" is very important both to students and teachers. Face as defined by Goffman (1967) as "the positive social value a person effectively claims for himself by the line others assume he has taken during a particular contact" which, however, "is only on loan to him from society" and "it will be withdrawn unless he conducts himself in a way that is worthy of it" (Goffman, 1972). Brown and Levinson

@ECRTD-UK https://www.eajournals.org/ 
(1987) describe face as "the public self-image that every member of a society seeks to claim for himself/herself" (p. 61) and distinguish between positive and negative face requirements.

Several factors are taken into account when someone wants to maintain face or, the fear of losing face in his/her community of practice to avoid misunderstanding and embarrassing situations.

In Albania keeping face, meaning not being shamed, is crucial. The teachers observed asked questions about the usage of prepositions to the class and picked a student to answer it. If that person didn't know the answer, he/she would lose face if he/she didn't know the answer because it makes him/her look unintelligent and unprepared. The student who is asked by the teacher tend to save his/her positive face (while providing correct answers) so he/she is liked and approved by the others; his answer is heard, and to some extent accepted by others.

During the observation hours several positive face threats were noticed, in which the teachers or students threatened the students (who were asked to provide answers)' positive face by appearing to pay little attention to their right to self-esteem:

(a) acts like:

- accuse:

eg.S: My mum goes to work with a car...

T: how come you still do not get it that in English we say by car... but on foot!

- criticize:

eg. Two of the teachers selected for this study continuously criticized their students of not studying and practicing English prepositions at home; devoting time to homework;

- disapprove:

eg. When students provided wrong answers teachers often use body language, verbal or non-verbal signs/language to show their disaprovement.

- insult or reprimand:

eg. Sometimes not only teachers insulted their students if they provided a wrong answer but also their peers insulted their classmates such as you do not know a thing or you are not clever enough...

(b) disruption of a turn and lack of active listening signals;

eg. Students most of the time interrupted each other if a wrong answer was given

@ECRTD-UK https://www.eajournals.org/ 
and also they didn't wait for their turn to participate in the activities. Occasionally teachers were not attentive while their students answered.

(c) forgetting the hearer's name, opinions, and so on;

eg. Most of the time teachers didn't call students by their names. Thy pointed or called them by nick names such as the Blondie, the girl with glasses etc.

During the observation hours several negative face threats were noticed, in which the teachers' or students' negative face is threatened.

Some negative face-threatening acts observed include:

(a) Request (perhaps the most face-threatening of its several forms, which can be as harsh as command or order) and require, which place pressure on students to perform something they may not want to do;

eg. Teachers called students to provide answers related to correct use of prepositions and didn't allow some thinking time.

(b) Acts such as advise or recommend are less forceful than requests, but they nevertheless place pressure on the listener to adopt the advice or follow the proposal.

eg. pay by check/credit card/ direct debit BUT we say pay in cash. come by car/train/plane/boat/ BUT we say come on foot.

(c) When acts like recall imply that the students have forgotten something and are thus at some level of (mild) blame, and when they are designed to imply that the students should do something,

eg. Teacher A reminded her students that they had to use lots of different types of prepositions to describe their daily routines.

(d) acts such as warn, which imply that the teacher will take action in the future to limit the students' freedom:

eg. I'm warning you do not take ready-made sentences with prepositions from the internet.

Strategies to save face negative face are referred to as negative politeness, whereas strategies meant to save positive face are called positive politeness (Chemiz, 2007). One of the teachers, Teacher A, often singled students out during her classes for lack of concentration or for providing wrong answers. These students lost their face with their 
peers. Teacher $\mathrm{B}$ and Teacher $\mathrm{C}$ corrected students one-on-one. Embarrassing or humiliating students can often crush their spirit and hinder the learning process.

In all the classes observed, students directed many questions to their teachers, in some cases not related to the discussion. It's a common belief, influenced by the intercultural interference of Albanian students who teachers are (considered as) "walking encyclopedias", they know everything and are able to provide answers for whatever questions their students might ask. They are esteemed for knowledge, wisdom and authority. As a result, teachers tend to save their faces by providing answers, in some cases they make up answers just for the sake of providing an answer. Often, a teacher who admits to being perplexed by a question will lose face and thus the respect of the students.

It is on mutual interest to save, maintain, or support each other's face (be it of the teachers' or the students'), face threating acts are either avoided (if possible) or different strategies can be employed to counteract or soften them.

Nevertheless, the strategies mentioned above are used employed according to the degree of face threat that a student or a teacher may encounter or estimate for an act. Students should be challenged to think about the variables that determine the assessment of the amount of face threat:

- relative power of the teacher - the greater the (perceived) relative power of the student over the teacher, the more politeness is recommended (relationship student-teacher, employeeboss).

- social distance (between the interlocutors) - the greater the social distance between the teachers and students or among studnets themselves (e.g., if they know each other very little more politeness is generally expected).

\section{DISCUSSION}

Teachers' beliefs and current practices are important for understanding and improving the educational processes. In the current study, the researchers attempted to compare the teachers' beliefs and their actual practices in English classes and how is the concept of face employed in EFL classes. As noted from Table 1 and Table 2, teachers' professional knowledge, their beliefs and actual practices differ among the three teachers selected for the actual study. So, although Teacher 1 believes that the best way to teach English

@ECRTD-UK https://www.eajournals.org/ 
prepositions is by providing lots of examples, what we noticed in her classes greatly differed from her beliefs. As already mentioned, Teacher 1 gave examples of the different activities she used with her students such as: "Listen and draw"; "Listen and do"; "Listen and write". In the classes that we observed Teacher 1, she didn't make use of any of the activities she mentioned, even though she may have used them while explaining simple prepositions such as: in, on, at, by, from, etc. Instead, she conducted teacher-centered classes, with explicit grammar rules explained first and then practiced in sentences, by the students. Positive and negative face threating acts were observed.

While observing Teacher 3, we noticed that she didn't provide any grammar rules, (how and where are certain prepositions used); instead, she engaged her students in different activities regarding prepositions' usage in different contexts. Nevertheless, she asked her students to state grammar rules (they had to figure out the rules from the examples). When asked why she said that students would learn best if their attention is focused on grammar rules. During the interview, her belief concerning the importance of knowing the grammar rules when and how prepositions are used, she said that there is no need to memorize rules; students will get the rules through examples. Positive and negative face threating acts were observed.

Teacher's 2 beliefs regarding prepositions matched her actual classroom practices. During the observations, we noticed that grammar was taught inductively, through examples and drills. During the interview, she stated that the process of learning a foreign language should be the same as the acquisition of mother tongue, so the rules necessary to practice the English will be figured out or induced from examples. During her classes, she made use of posters, flashcards and different photos to illustrate the usage of certain prepositions. Positive and negative face threating acts were observed.

When we started to analyze the data gathered from the interviews and the classroom observations, we tried to think of possible reasons for some of the divergences noted between teachers' beliefs and their actual classroom practices.

When the three teachers were asked about the importance of prepositions in the process of the acquisition of a foreign language, they stated that generally teachers do not spend so much time on their explanation due to several reasons: lack of time, some of them think they are not so important, lack of confidence, teachers want to save their faces (if a student asks grammar information on the usage of a specific preposition, the belief is that teachers should always provide the correct answer). 
We think time factor plays a crucial role. The three teachers emphasized the notion of "time" as a very important aspect of teaching. Teacher 1 stated that: in 45 min you can't spend 20 minutes explaining prepositions and practicing them in different contexts, due to the restrains put by the English curricula and daily lesson plans." Teacher 2 argued that she uses mostly the inductive method of teaching grammar, because it is more economical in time, but at the same time it's more appreciated by the students.

Teacher 1 and Teacher 2 that were selected for this study were not consciously familiar of their beliefs about prepositions and the way they are taught or should be taught. Teacher 3 was more aware of prepositions due to previous trainings regarding the importance of prepositions in the teaching process.

Teachers were not asked specific questions regarding the concept of face. We doubt if they have information on the concept of face, types of face and strategies to strengthen or weaken face threatening acts. For the purpose of this paper, we consulted our field notes, recordings to elicit and see examples of face threatening acts.

\section{CONCLUSION}

The study was done to investigate the stated beliefs and actual classroom practices of three English teachers in two primary schools in Tirana, Albania. The findings reveal that teachers have some beliefs regarding English prepositions, and sometimes they didn't match their actual classroom practices due to various reasons.

Going back in the years when we were Bachelors students and later Master Program students, we do not recall any of our professors introducing us with the concept of face (providing us with scientific/theoretical/practical information on the concept of face). We came across this concept when we were researching and gathering information about our PhDs. So, we strongly believe that students should be taught about the concept of face, types of face, how they are related to individuals and the influence that the concept of face has on teachers' daily teaching routines.

The results of this paper cannot be generalized for all English language teachers of Albania. Further studies are needed on the importance of prepositions, teachers' beliefs and classroom practices (a larger sample is needed) but also additional studies are needed on the degree of difficulties that the EFL teachers face while they deal or try to teach

@ECRTD-UK https://www.eajournals.org/ 
English prepositions. Moreover, there is no study on the concept of face in the Albanian context and especially in the EFL classes. So, in the future other studies are needed to stress the importance of the concept of face in the Albanian culture.

\section{REFERENCES}

Bell, C. L., \& Robinson, N. G. (2004). The successful student teaching experience: Thoughts from the Ivory Tower. Music Educators Journal, 91, 39-42.

Borg, S. (2003). Teacher cognition in language teaching: a review of research on what language teachers think, know, believe, and do. Language Teaching 36,2 April 2003, 81- 109

Brown, P. \& S. C. Levinson. (1978). Universals in Language Usage: Politeness Phenomenon. In: E. Goody (Ed.), Questions and Politeness: Strategies in Social Interaction. Cambridge: Cambridge University Press.

Brown, P. \& S. C. Levinson. (1987). Politeness: Some Universals in Language Use. Cambridge, UK: Cambridge University Press.

Celce-Murcia, M. \& Larsen-Freeman, D. (1999). The Grammar Book: An ESL/EFL Teacher's Course (2nd edition).USA: Heinle \& Heinle Publishers

Curtner-Smith, M. D., Hastie, P. A., \& Kinchin, G. D. (2008). Influence of occupational socialization on beginning teachers' interpretation and delivery of sport education. Sport Education and Society, 13,(1), 97e117.

Demiraj, Sh., (1986). Gramatika Historike e gjuhës shqipe", Tiranë.

Dheri, V. (1984). "Parafjalët e gjuhës angleze, vështruar në rrafshin gjuhësor përqasës dhe metodik" vepër e pabotuar.

Evans V., O'Sullivan～N., Click on 1.2.3., Express Publishing, 2001

Farrell, T.S.C. (2004b). Reflecting on classroom communication in Asia. Singapore: Longman.

Gass, S. \& Mackey, A. (2013). Research Methods in Second Language Acquisition available at https://onlinelibrary.wiley.com/doi/book/10.1002/9781444347340

Goffman, E. (1972). On Facework: an Analysis of Ritual Elements in Social Interaction. In: J. Laver and S. Hutcheson, (Eds.), Communication in Face-to-face Interaction, 319-346. Harmondsworth: Penguin.

Goffman, E. (1967). Interaction Ritual: Essays on Face-to-face Behavior. New York: Doubleday.

Heath, C. (2011). Embodied action: Video and the analysis of social interaction. David Silverman Qualitative Research, $3^{\text {rd }}$ edition, ch. 14

James, M. (2007). Interlanguage variation and transfer of learning [Electronic version]. International review of applied linguistics in language teaching, 45, 95-118.

@ECRTD-UK https://www.eajournals.org/

https://doi.org/10.37745/ejells.2013 
European Journal of English Language and Literature Studies

Vol.10, No.1, pp.1-15, 2021

Print ISSN: 2055-0138(Print),

Online ISSN: 2055-0146(Online)

Jie, X. (2008). Error theories and second language acquisition [Electronic version]. USChina foreign language, 6(1), 35-42.

Johnson, K. E. (1994). The emerging beliefs and instructional practices of preservice English as a second language teachers. Teaching \& Teacher Education, 10 (4): 439-452.

Kay S., Kerr P., 2003, Inside Out Macmillan ELT

Kerr P., Jones C., 2007, Straightforward Upper Intermediate, Macmillan Education

Ng, E. K. J., \& Farrell, T.S.C. (2003). Do Teachers' Beliefs of Grammar Teaching Match their Classroom Practices? A Singapore Case Study. In D. Deterding. Brown A \& Low E L (Eds. 2003) English in Singapore: Research on Grammar. Singapore (pp. 128-137): McGraw Hill, 128-137.

Pajares, M. F. (1992). Teachers' beliefs and educational research: Cleaning up a messy construct. Review of Educational Research, 62(3), 307-332.

Richardson, R. (1996). The role of attitude and beliefs in learning to teach. In J. Sikula, T. Buttery, \& E. Guyton (Eds.), Handbook of research on Teacher Education (2nd ed., pp.102-119). New York: Macmillan.

Samara, M., (1999). "Parafjalët në shqipen e sotme”, Tiranë

Schweisfurth, M. (2015). Learner-centred pedagogy: Toward a post-2015 agenda for teaching and learning. International Journal of Educational Development, 40, 259-266. doi:10.1016/j.ijedudev.2014.10.011

Stempleski, S, Douglas, N., Morgan , R. J., (2004). World Link, Heinle ELT; 1 edition.

Shavelson, R. J., \& Stern, P. (1981). Research on teachers' pedagogical thoughts, judgements, decisions, and behaviour. Review of Educational Research, 51, 455-498.

Tillema, H. H. (2000). Belief change towards self-directed learning in student teachers: immersion in practice or reflection on action. Teaching and Teacher Education, 16, 575-591.

Tobin, K., Tippins, D. J., \& Gallard, A. J. (1994). Research on instructional strategies for teaching science. In D. L. Gabel (Ed.), Handbook of research on science teaching and learning (pp. 45-93). New York: Macmillan.

Yin, R. (2003). Case Study Research (3d ed. ). Thousand Oaks, CA: Sage

@ECRTD-UK https://www.eajournals.org/

https://doi.org/10.37745/ejells.2013 